\title{
Occurrence, harmfulness and dynamic of cereal leaf miners (Agromyzidae) flight on winter wheat in Wielkopolska region
}

\author{
Występowanie, szkodliwość i dynamika lotu miniarek (Agromyzidae) \\ występujących w uprawie pszenicy ozimej na terenie Wielkopolski
}

\author{
Kamila Roik ${ }^{1}$, Andrzej Bandyk $^{1}$, Beata Wielkopolan ${ }^{1}$, Jan Bocianowski ${ }^{2}$
}

\begin{abstract}
Summary
Leaf miners from the family of Agromyzidae commonly occur in cereal crops on the territory of the whole country. However, their harmfulness is not considered as very high, and only locally they can cause losses of economic importance. Feeding larvae damage leaves of winter wheat and barley reducing the yield parameters. Monitoring of cereal leaf miners flight in winter wheat crops was carried out in Wielkopolska district in 2009/2010 and 2010/2011 in Słupia Wielka. Yellow traps were placed above the top of wheat plants during the vegetation period. The traps were replaced once a week. Fluctuations in weather conditions during the studies affected the dynamics of leaf miner flies considerably. The most common species were: Chromatomyia nigra (Mg.), Ch. fuscula (Ztt.) and Poemyza superciliosa (Ztt.). At the same time observations were carried out to determine the harmfulness of leaf miners and leaves with visible presence of larvae or pupa stage in leaf tissue were collected. In laboratory conditions, the culturing was carried out in order to determine the species of leaf miner.
\end{abstract}

Key words: leaf miners, Agromyzidae, winter wheat, harmfulness, dynamics

\section{Streszczenie}

Muchówki z rodziny miniarkowatych (Agromyzidae) występują powszechnie na zbożach na terenie całego kraju. Ich szkodliwość nie jest tak duża, jak mszyc czy skrzypionek, jednak lokalnie zdarza się, że powodują straty o znaczeniu gospodarczym. Żerujące larwy mogą uszkadzać liście nawet kilkudziesięciu procent źdźbeł pszenicy i jęczmienia ozimego wpływając na pogorszenie parametrów plonu. Monitoring lotu muchówek miniarek na plantacji pszenicy ozimej w warunkach Wielkopolski prowadzono w sezonach wegetacyjnych 2009/2010 i 2010/2011, w Słupi Wielkiej (powiat średzki). Do odłowów wykorzystano 3 żółte tablice pokryte klejem o wymiarach $25 \times 40 \mathrm{~cm}$ (producent: BioBest, Belgia), które ustawiono losowo na plantacji. Tablice zawieszano na palikach umożliwiających ich stopniowe podnoszenie, w miarę wzrostu roślin tak, aby tablice znajdowały się tuż nad łanem. Tablice zmieniano raz w tygodniu. Ze względu na zróżnicowane warunki pogodowe w każdym sezonie wegetacyjnym dynamika lotu muchówek miniarek przebiegała inaczej. Dominującymi gatunkami w latach badań były: Chromatomyia nigra (Mg.), Ch. fuscula (Ztt.) i Poemyza superciliosa (Ztt.). Równocześnie prowadzono obserwacje w celu określenia szkodliwości miniarek oraz zbierano liście z widocznymi wewnątrz larwami lub bobówkami. W warunkach laboratoryjnych prowadzono ich hodowlę w celu oznaczenia występujących gatunków miniarek.

Słowa kluczowe: miniarki, Agromyzidae, pszenica ozima, szkodliwość, dynamika

\footnotetext{
${ }^{1}$ Instytut Ochrony Roślin - Państwowy Instytut Badawczy

Zakład Metod Prognozowania Agrofagów i Ekonomiki Ochrony Roślin

Władysława Węgorka 20, 60-318 Poznań

K.Roik@iorpib.poznan.pl

${ }^{2}$ Uniwersytet Przyrodniczy w Poznaniu

Katedra Metod Matematycznych i Statystycznych

Wojska Polskiego 28, 60-637 Poznań
} 


\section{Wstęp / Introduction}

Od początku lat dziewięćdziesiątych XX wieku obserwuje się ponowny wzrost liczebności i szkodliwości muchówek z rodziny miniarkowatych (Agromyzidae), które wcześniej nie miały znaczenia gospodarczego. W Polsce na zbożach występuje kilkanaście gatunków miniarek. Stadium szkodliwym są larwy, które powodują charakterystyczne uszkodzenia zwane „minami” (Roik i wsp. 2011). Żerujące larwy mogą uszkadzać liście nawet kilkudziesięciu procent źdźbeł pszenicy wpływając na pogorszenie parametrów plonu.

Potrzeba ochrony plantacji najczęściej jest stwierdzana w momencie zauważenia rozległych uszkodzeń (,min”), kiedy na chemiczne zwalczanie tych szkodników jest już za późno. Dotychczas przeprowadzone badania w aspekcie chemicznego zwalczania tych szkodników wykazały, że dobrą praktyczną metodą prognozowania krótkoterminowego może być kontrola dynamiki lotu form dorosłych miniarek, odławianych na żółtych tablicach klejowych (Walczak i wsp. 2009), przy równoległej obserwacji rozwoju skrzypionek (Walczak 1998).

Celem badań było określenie nasilenia występowania, szkodliwości oraz dynamiki miniarek (Agromyzidae) występujących na pszenicy ozimej.

\section{Materiały i metody / Materials and methods}

W sezonach wegetacyjnych 2009/2010 i 2010/2011 na terenie Wielkopolski w miejscowości Słupia Wielka (powiat średzki) przeprowadzono doświadczenia ścisłe z pszenicą ozimą odmiany Bogatka. Do odłowów wykorzystano żółte tablice pokryte klejem o wymiarach $25 \times 40 \mathrm{~cm}$ (producent: BioBest, Belgia). Tablice zmieniano raz w tygodniu w okresie od 12.04 do $14.06 \mathrm{w}$ roku $2010 \mathrm{i}$ od 11.04 do $13.06 \mathrm{w}$ roku 2011. Wynik podano jako średnią liczbę złowionych muchówek z trzech tablic na każdej plantacji. Równocześnie prowadzono wizualną ocenę rozwoju skrzypionek, odnotowując aktualne występujące stadium.

Terminy zabiegów wyznaczano według następujących kryteriów:

- pierwszy zabieg: na podstawie wyraźnego wzrostu liczebności odłowionych muchówek za pomoca żółtych tablic i po stwierdzeniu chrząszczy oraz jaj skrzypionek,

- drugi zabieg: w okresie dalszego licznego lotu miniarek, gdy jednocześnie najstarsze larwy skrzypionek osiaggną wielkość około $2 \mathrm{~mm}$ (Walczak 1998),

- trzeci zabieg: w okresie nadal licznego lotu miniarek, gdy jednocześnie najstarsze larwy skrzypionek osiągną wielkość około $4 \mathrm{~mm}$.

Skuteczność zabiegów przeprowadzonych w terminach wyznaczonych, zgodnie z powyższymi kryteriami, oceniono na podstawie wielkości uzyskanego plonu w obrębie każdej kombinacji. Zabiegi wykonywano z użyciem preparatu Bi 58 Nowy 400 EC (2009) w dawce 0,5 1/ha.

$\mathrm{Na}$ wybranych plantacjach pszenicy ozimej prowadzono także obserwacje, które miały na celu określenie liczby źdźbeł z uszkodzonymi liśćmi. Wynik wyrażono w liczbie min na 100 analizowanych źdźbeł. Ponadto w celu określenia liczebności miniarek $\mathrm{W}$ maju $\mathrm{z}$ poletek doświadczalnych i na wybranych plantacjach pszenicy pobierano liście $\mathrm{z}$ widocznymi wewnątrz larwami lub bobówkami do hodowli, w wyniku której uzyskiwano imagines. Hodowlę prowadzono w warunkach laboratoryjnych w temperaturze $20-22^{\circ} \mathrm{C}$ oraz wilgotności $40-60 \%$. Charakterystyczne dla danego gatunku miny na liściach pszenicy ozimej identyfikowano na podstawie klucza (Beiger 2004). Identyfikacje gatunków miniarek przeprowadzono na podstawie preparowania aparatów płciowych samców (Beiger 1989).

Otrzymane wyniki analizowano statystycznie. Dwuczynnikowa (rok, termin zabiegu) analiza wariancji (ANOVA) została przeprowadzona w celu zweryfikowania hipotez zerowych o braku wpływu lat i terminu zabiegu oraz hipotezy zerowej o braku interakcji rok $\times$ termin zabiegu na liczbę występujących miniarek oraz plon. Współzależność pomiędzy liczbą miniarek a plonem oceniano za pomocą współczynnika korelacji (Kozak i wsp. 2010). Analiza regresji wielokrotnej posłużyła do zweryfikowania hipotezy, czy temperatura i opady determinowały istotnie występowanie miniarek. Wszystkie obliczenia w zakresie analizy danych wykonano przy użyciu pakietu statystycznego GenStat 15 th.

\section{Wyniki i dyskusja / Results and discussion}

Dynamika lotu miniarek na plantacje pszenicy ozimej w poszczególnych sezonach wegetacyjnych była zróżnicowana $\left(\mathrm{F}_{1,24}=6,62, \mathrm{Lp}=0,017\right)$. W 2010 roku pierwsze miniarki zaobserwowano $\mathrm{w}$ połowie kwietnia. W tygodniu, w którym stwierdzono maksimum lotu odłowiono średnio 30,33 owadów dorosłych na tablicy żółtej (rys. 1).

W 2011 roku pierwsze muchówki pojawiły się na plantacjach pszenicy ozimej także w drugiej dekadzie kwietnia. W tygodniu, w którym stwierdzono maksimum lotu odłowiono średnio 39,67 owadów dorosłych na tablicy żółtej (rys. 2).

Na podstawie odłowów muchówek i obserwacji dotyczących rozwoju skrzypionek wyznaczono terminy zabiegów przeciwko obu szkodnikom oraz oceniono wysokość zebranego plonu uzyskanego z poszczególnych kombinacji (tab. 1). Terminy zabiegów chemicznych w doświadczeniu to odpowiednio 21.05, 02.06, 08.06 w roku 2010 oraz 18.05, 26.05 i $01.06 \mathrm{w}$ roku 2011. W obu latach badań optymalny termin zabiegu przypadł w okresie trwania licznego lotu muchówek i jednocześnie, gdy najstarsze larwy skrzypionek osiągnęły wielkość około $2 \mathrm{~mm}$.

W 2010 r. zaobserwowano średnio 5 min na 100 analizowanych źdźbeł, natomiast w 2011 r. do $12 \mathrm{~min}$ na 100 analizowanych źdźbeł (tab. 2).

W latach 2010 i 2011 liczba liści uszkodzonych przez larwy miniarek spadła w porównaniu z poprzednimi, gdzie w 2007 roku obserwowano średnio do 16 min na 100 analizowanych źdźbeł (tab. 2). Jedną z głównych przyczyn mogą być różnice $\mathrm{w}$ warunkach pogodowych w badanych latach. Długa i mroźna zima 2009/2010 i 2010/2011 oraz 


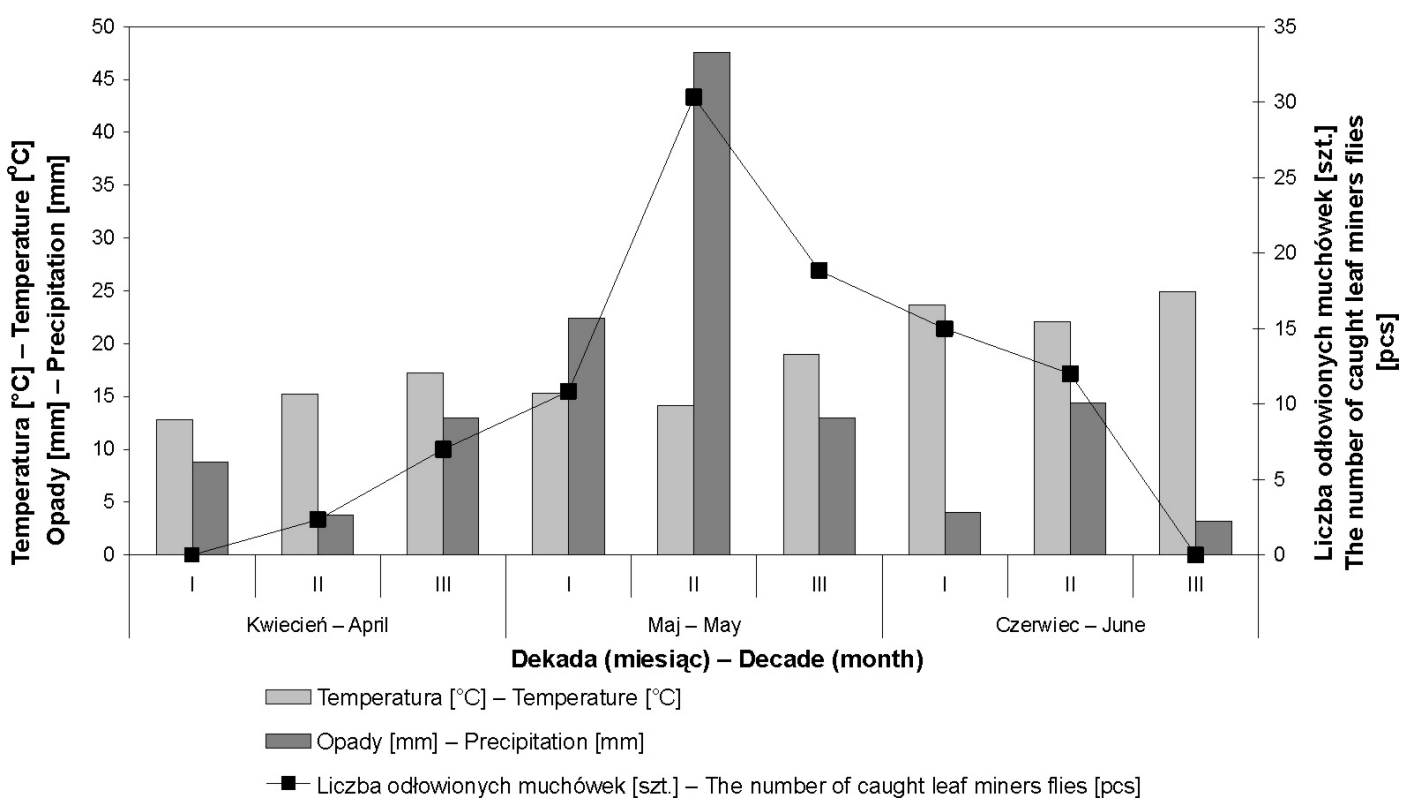

Rys. 1. Dynamika lotu muchówek miniarek występujących na zbożach w Słupi Wielkiej w 2010 r. na tle warunków atmosferycznych Fig. 1. Dynamics of ceral leaf miners flies in Baborówko in local meteorological conditions in 2010 in Słupia Wielka

\section{1}

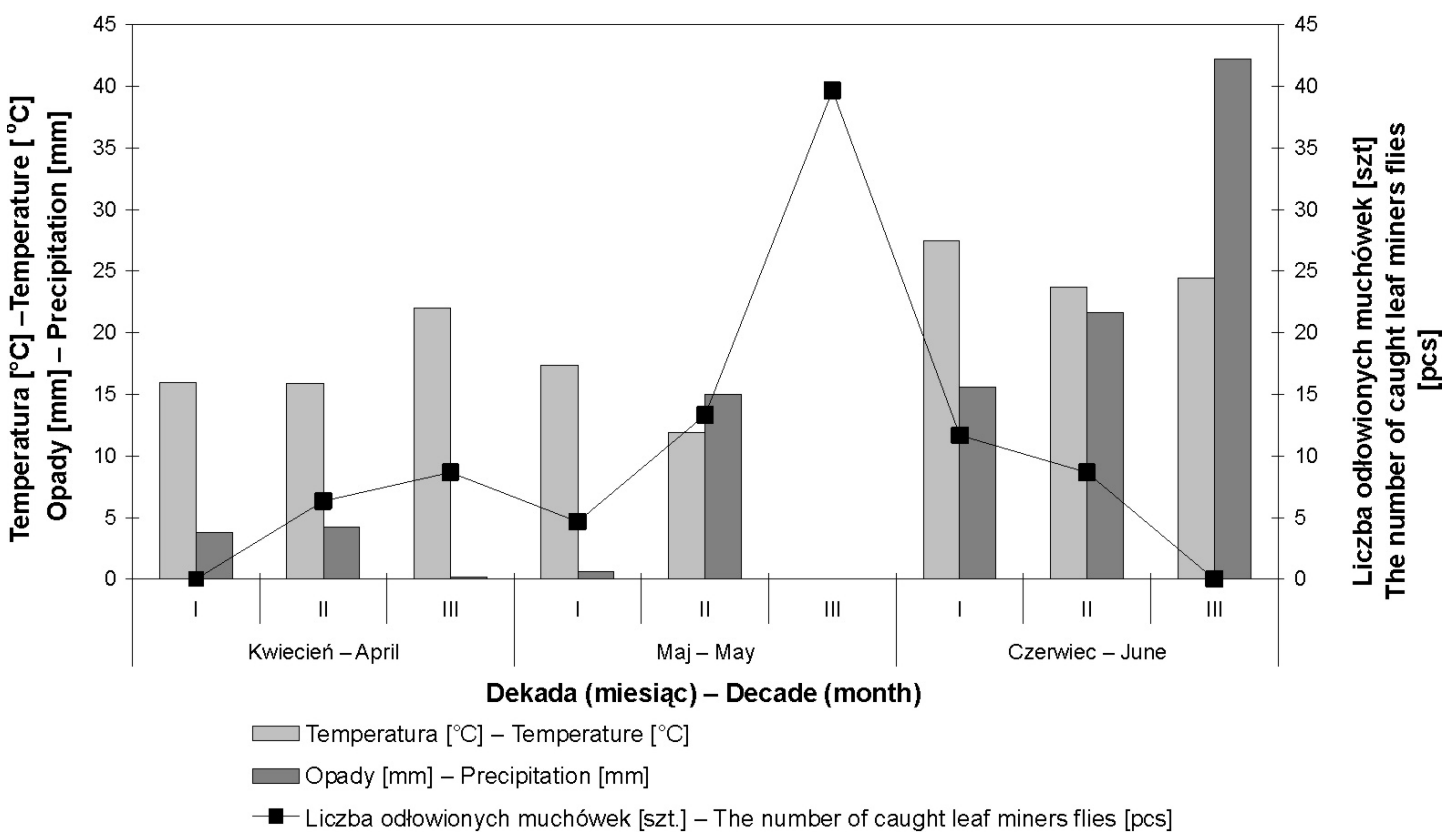

Rys. 2. Dynamika lotu muchówek miniarek występujących na zbożach w Słupi Wielkiej w 2011 r. na tle warunków atmosferycznych Fig. 2. Dynamics of ceral leaf miners flies in Baborówko in local meteorological conditions in 2011 in Słupia Wielka

wiosenne przymrozki przyczyniły się do późniejszych nalotów szkodników na plantacje pszenicy ozimej.

W 2010 roku do hodowli w laboratorium pobrano łącznie 57 liści z larwami lub bobówkami wewnątrz min. Do stadium bobówki wyhodowano 52 osobniki. Stadium imago osiągnęły 42 osobniki. Ponadto do stadium imago z pobranych do hodowli larw i bobówek miniarek rozwinęły się dwie błonkówki pasożytnicze (tab. 3).
W 2011 roku do hodowli w laboratorium pobrano łącznie 117 liści z larwami lub bobówkami wewnątrz min. Do stadium bobówki wyhodowano 98 osobników. Stadium imago osiagnęło 87 osobników. Ponadto do stadium imago z pobranych do hodowli larw i bobówek miniarek rozwinęły się dwie błonkówki pasożytnicze (tab. 3).

Dominującymi gatunkami w latach badań były: Chromatomyia nigra (Mg.), Ch. fuscula (Ztt.) i Poemyza superciliosa (Ztt.). 
Tabela 1. Plony pszenicy \pm odchylenia standardowe $\mathrm{z}$ poszczególnych kombinacji w latach 2010-2011

Table 1. Yields \pm standard deviations from particular combinations in 2010-2011

\begin{tabular}{l|c|c}
\hline \multirow{2}{*}{$\begin{array}{c}\text { Kombinacja } \\
\text { Combination }\end{array}$} & \multicolumn{2}{|c}{$\begin{array}{c}\text { Plon - Yield } \\
{[\mathrm{kg} \pm \mathrm{SD}]}\end{array}$} \\
\cline { 2 - 3 } $\begin{array}{l}\text { Kontrola } \\
\text { Control }\end{array}$ & $13,57 \pm 1,81$ & $14,90 \pm 0,93$ \\
\hline $\begin{array}{l}\text { 1 termin zabiegu } \\
\text { 1st date of treatment }\end{array}$ & $12,90 \pm 1,83$ & $14,65 \pm 0,77$ \\
\hline $\begin{array}{l}\text { 2 termin zabiegu } \\
\text { 2nd date of treatment }\end{array}$ & $15,20 \pm 1,71$ & $15,30 \pm 0,75$ \\
\hline $\begin{array}{l}\text { 3 termin zabiegu } \\
\text { 3rd date of treatment }\end{array}$ & $14,60 \pm 2,20$ & $16,70 \pm 1,25$ \\
\hline
\end{tabular}

SD - standard deviation - odchylenie standardowe

Tabela 2. Liczba min liściowych stwierdzona na poletkach doświadczalnych pszenicy ozimej w latach 2010 i 2011 oraz dla porównania w roku 2007 (liczba $\mathrm{min} / 100$ źdźbeł)

Table 2. The number of leaf mines the found on experimental plots of winter wheat in 2010 and 2011 and for comparison in 2007 (the number of mines/100 culms)

\begin{tabular}{c|c|c}
\hline $\begin{array}{c}\text { Rok } \\
\text { Year }\end{array}$ & $\begin{array}{c}\text { Data } \\
\text { Date }\end{array}$ & $\begin{array}{c}\text { Liczebność } \\
\text { The numbers }\end{array}$ \\
\hline 2007 & 18.05 & 16 \\
\hline 2010 & 21.05 & 5 \\
\hline 2011 & 18.05 & 12 \\
\hline
\end{tabular}

Tabela 3. Liczba zebranych liści oraz bobówek, muchówek miniarek i pasożytniczych błonkówek w hodowli laboratoryjnej w 2010 i 2011 roku

Table 3. The number of puparium, imagines bred in laboratory conditions in the years 2010-2011

\begin{tabular}{l|c|c|c|c}
\hline $\begin{array}{c}\text { Rok } \\
\text { Year }\end{array}$ & $\begin{array}{c}\text { Liczba } \\
\text { zebranych } \\
\text { liści } \\
\text { Number } \\
\text { of leaves } \\
\text { collected }\end{array}$ & $\begin{array}{c}\text { Liczba } \\
\text { bobówek } \\
\text { Bred to the } \\
\text { grub stage }\end{array}$ & $\begin{array}{c}\text { Liczba } \\
\text { muchówek } \\
\text { Bred to the } \\
\text { fly stage }\end{array}$ & $\begin{array}{c}\text { Liczba } \\
\text { pasożytniczych } \\
\text { błonkówek } \\
\text { The number } \\
\text { of parasitic } \\
\text { Hymenoptera }\end{array}$ \\
\hline 2010 & 57 & 52 & 42 & 2 \\
\hline 2011 & 117 & 98 & 87 & 2 \\
\hline $\begin{array}{l}\text { Razem } \\
\text { Total }\end{array}$ & 174 & 140 & 129 & 4 \\
\hline
\end{tabular}

Porównując uzyskane wyniki z badaniami wcześniej przeprowadzonymi przez innych autorów (Soczyński 1984; Beiger 1988; Walczak 1995, 1998) stwierdzono, że skład gatunkowy miniarek występujących na pszenicy ozimej zmienia się w poszczególnych latach. Otrzymane wyniki różnią się w porównaniu do wcześniejszych badań. W latach 1995-1998 w uprawach zbóż wykazano takie gatunki miniarek, jak: Phytomyza nigra (Mg.) i Agromyza ambiqua (Fll.), A. mobilis (Mg.), Cerodontha pygmaea (Mg.) (Walczak 1998).
Tabela 4. Model regresyjny temperatury i opadów na występowanie miniarek

Table 4. Regression model of temperature and rainfall on the occurrence of leaf miners

\begin{tabular}{l|c|c}
\hline \multicolumn{1}{c|}{$\begin{array}{c}\text { Źródło zmienności } \\
\text { Source of variation }\end{array}$} & $\begin{array}{c}\text { Stopnie } \\
\text { swobody } \\
\text { Degrees } \\
\text { of freedom }\end{array}$ & Średni kwadrat \\
Mean squares
\end{tabular}

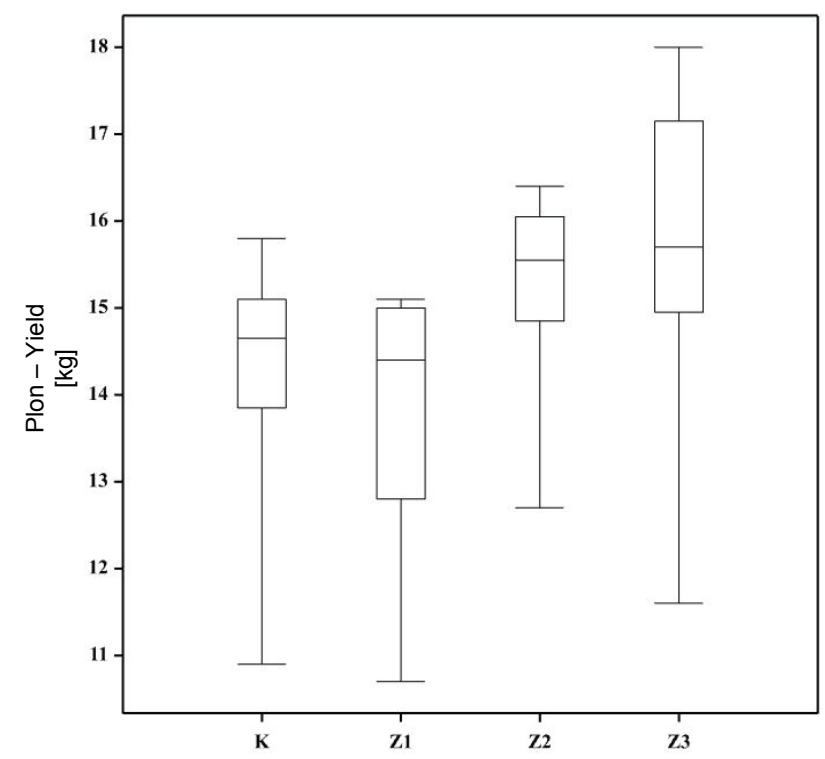

Rys. 3. Wykres pudełkowy wielkości uzyskanego plonu w badaniach terminu zabiegu ( $\mathrm{K}$ - kontrola, $\mathrm{Z1}$ - I termin zabiegu, Z2 - II termin zabiegu, Z3 - III termin zabiegu)

Fig. 3. Boxplot of the values of yield, classified by the date of treatment $(\mathrm{K}$ - control, $\mathrm{Z1}$ - 1st date of treatment, $\mathrm{Z} 2$ 2nd date of treatment, $\mathrm{Z3}$ - 3rd date of treatment)

Wyniki przeprowadzonej analizy wariancji wskazuja na istotny statystycznie wpływ lat prowadzenia obserwacji $\left(\mathrm{F}_{1,24}=6,19 ; \quad \mathrm{Lp}=0,020\right) \quad$ oraz terminu zabiegu $\left(\mathrm{F}_{3,24}=3,70 ; \mathrm{Lp}=0,041\right)$ na wielkość uzyskanego plonu. Średnio najmniejszy plon obserwowano dla pierwszego terminu zabiegu, a największy dla trzeciego terminu zabiegu (rys. 3). 
Przeprowadzona analiza korelacji wykazała brak współzależności pomiędzy liczbą miniarek a wielkością obserwowanego plonu $(\mathrm{r}=-0,0027 ; \mathrm{p}=0,9885)$. Wcześniejsze badania (Roik i wsp. 2012) wykazały istotność współzależności pomiędzy liczbą miniarek a plonem.

Wyniki analizy regresji wskazują na istotny statystycznie wpływ opadów na występowanie miniarek (tab. 4). Procent zmienności w występowaniu miniarek był $\mathrm{w} 11,0 \%$ wyjaśniany warunkami atmosferycznymi $\mathrm{w}$ postaci zmiennej temperatury i opadów (tab. 4).

Uzyskane wyniki zachęcają do kontynuacji podjętego tematu. Koncepcja badań jest bardzo potrzebna. W kolejnych badaniach planuje się skonkretyzowanie podejścia do modelowania czynników abiotycznych. Znaczna zmienność tych czynników wymaga analizy danych z większą częstością.

\section{Wnioski / Conclusions}

1. Maksimum nalotu muchówek miniarek na plantacje pszenicy ozimej w Wielkopolsce w latach badań miało miejsce w maju.

2. Dynamika lotu muchówek miniarek na plantacjach pszenicy ozimej charakteryzuje się dużą zmiennością, stąd konieczne jest coroczne prowadzenie monitoringu w odniesieniu do konkretnej plantacji.

3. W roku 2011 liczba liści uszkodzonych przez larwy miniarek wyraźnie zwiększyła się w porównaniu do roku 2010.

4. Gatunkami miniarek występującymi w latach badań na plantacjach pszenicy ozimej były: Ch. fuscula (Ztt.), Ch. nigra (Ztt.) i mniej liczna $P$. superciliosa (Ztt.).

5. Wyniki niniejszych badań wzbogacą wiedzę dotyczącą ograniczenia liczebności i szkodliwości miniarek oraz skrzypionek na plantacjach zbóż w kontekście integrowanej ochrony zbóż.

\section{Literatura / References}

Beiger M. 1988. Materiały do znajomości owadów minujących runa lasów olchowych Wielkopolski. Bad. Fizjogr. Pol. Zach. 37, Seria C: $5-22$.

Beiger M. 1989. Miniarki (Agromyzidae) - szkodniki roślin użytkowych. Wyd. Nauk. Uniwersytetu im. A. Mickiewicza, Poznań, 155 ss.

Beiger M. 2004. Owady minujące Polski. Klucz do oznaczania na podstawie min. Bogucki, Wyd. Nauk., Poznań, 893 ss.

Kozak M., Bocianowski J., Sawkojć S., Wnuk A. 2010. Call for more graphical elements in statistical teaching and consultancy. Biometrical Letters 47 (1): 57-68.

Roik K., Walczak F., Bandyk A., Kubsik K. 2011. Uszkodzenia powodowane przez muchówki z rodziny Agromyzidae na wybranych plantacjach pszenicy ozimej w Wielkopolsce. [Damages caused by leaf miners flies (Agromyzidae) on winter wheat plantations in Wielkopolska]. Prog. Plant Prot./Post. Ochr. Roślin 51 (2): 609-613.

Roik K., Bandyk A., Wielkopolan B., Kubsik K., Bocianowski J. 2012. Skład gatunkowy i dynamika występowania muchówek $\mathrm{z}$ rodziny miniarkowatych (Agromyzidae) w uprawie pszenicy ozimej. [Species comosition and dynamics of cereal leaf miners (Agromyzidae) flies on winter wheat]. Prog. Plant Prot./Post. Ochr. Roślin 52 (3): 541-545.

Soczyński G. 1984. Badania nad szkodliwością larw muchówek miniarkowatych (Diptera, Agromyzidae) żerujących na liściach pszenicy ozimej i jęczmienia jarego. Rocz. Nauk Rol. Seria E, 14 (1-2): 89-101.

Walczak F. 1995. Miniarki (Agromyzidae) - szkodniki upraw zbożowych. Materiały 35. Sesji Nauk. Inst. Ochr. Roślin, cz. 2: $15-18$.

Walczak F. 1998. System for warning and control of leaf mining flies and leaf beetles on cereal crops. J. Plant Prot. Res. 38 (1): $65-69$.

Walczak F., Gałęzewski M., Rosiak K., Kubsik K. 2009. Dynamika lotu miniarek (Agromyzidae) występujących na pszenicy ozimej w warunkach Wielkopolski. [Dynamic of ceral leaf miners (Agromyzidae) flight on winter wheat in Wielkopolska region]. Prog. Plant Prot./Post. Ochr. Roślin 49 (2): 577-580. 